\title{
Antioxidant and antidiabetic activities of various solvent extracts from Stachys sieboldii Miq.
}

\author{
Jae-Ran Kang ${ }^{1}$, Min-Jung Kang ${ }^{1}$, Ji-Hyeon Shin ${ }^{1}$, Ji-Hye Park ${ }^{1}$, Dong-il Kim ${ }^{2}$, \\ Sang-Yong Chung ${ }^{2}$, Jung-Hye Shin ${ }^{1 *}$ \\ ${ }^{1}$ Namhae Garlic Research Institute, Namhae 52430, Korea \\ ${ }^{2}$ Dongui-Chosukjam Farming Association Corporation, Sancheong 52242, Korea
}

\section{용매별 초석잠 추출물의 항산화 및 항당뇨 활성}

\author{
강재란 $^{1} \cdot$ 강민정 $^{1} \cdot$ 신지현 $^{1} \cdot$ 박지혜 $^{1} \cdot$ 김동일 $^{2} \cdot{\text { 정상 }^{2}}^{2} \cdot$ 신정혜 $^{1 *}$ \\ ${ }^{1}($ 재 $)$ 남해마늘연구소, ${ }^{2}$ 동의초석잠영농조합법인
}

\begin{abstract}
This study investigated the antioxidant and antidiabetic activities of Stachys sieboldii Miq. extracts by solvents (water, ethanol, butanol, chloroform, and hexane). The contents of total polyphenols (7.18-37.25 mg/g) and flavonoids $(0.21-5.21 \mathrm{mg} / \mathrm{g})$ in extracts from Stachys sieboldii Miq. showed a significant difference dependent on the extraction solvents, butanol $>$ ethanol $>$ water $>$ chloroform $>$ hexane. Antioxidant activities by DPPH and ABTS radical scavenging were increased in a dose-dependent manner. These activity trends associated with the extraction solvent were different at each concentration, but resembled phenolic compound contents trend, generally. FRAP value increased in a dose-dependent manner, but there was a difference in radical scavenging activities when comparing between extraction solvents by butanol $>$ ethanol $>$ hexane $>$ chloroform $>$ water on all concentrations. The trend of $a$-amylase inhibition of extracts from $1,000 \mu \mathrm{g} / \mathrm{mL}$ to $2,000 \mu \mathrm{g} / \mathrm{mL}$ was not affected as enzyme activity is promoted and not inhibited. The inhibition of a-glucosidase was increased in a dose-dependent manner without water extracts, the activity on hexane extracts was higher than others per the extraction solvent. a-Glucosidase inhibition of hexane extracts showed $57.76 \%$ at $250 \mathrm{\mu g} / \mathrm{mL}$, which is 2.8 times higher than the second highest chloroform extract $(20.65 \%)$. From these results, we presume that the active ingredients of Stachys sieboldii Miq. is different according to the extraction solvent and also the activity is different by these major functional groups.
\end{abstract}

Key words : Stachys sieboldii Miq., biological activity, antioxidant activity, a-glucosidase inhibition, a-amylase inhibition

\section{서 론}

시간이 경과함에 따라 생체 내 여러 가지 생리적 기능이 저하되는 현상을 뜻하는 “노화”는 외부로부터 오는 스트레 스를 감당하지 못하게 되는 상태를 의미한다(1). 인간은

*Corresponding author. E-mail : whanbee@daum.net Phone : 82-55-860-8947, Fax : 82-55-860-8960

Received 10 July 2017; Revised 18 August 2017; Accepted 18 August 2017.

Copyright (c) The Korean Society of Food Preservation. All rights reserved.
연령의 증가에 따른 노화현상으로 생리적 기능이 저하되고 면역기능이 약화됨으로써 동맥경화, 고혈압, 당뇨병 등 여 러가지 퇴행성 질환을 동반하는 것으로 보고되어 있다(1). 활성산소종(reactive oxygen species, ROS)은 노화를 일으키 는 직접적인 원인이 되는 물질로 지질, 단백질, 핵산 등을 손상시키고, 산화 스트레스(oxidative stress)를 유발하여 암, 당뇨, 동맥경화 등과 같은 여러 질병을 야기한다(2). 이에 활성산소나 라디칼을 제거함으로써 노화를 억제하고 질병 을 예방-치료하고자 하는 움직임이 활발하여 활성산소종을 제거하는데 관여하는 항산화제에 관심이 집중되고 있다 $(1,3)$. 또한 식물성 식품에 널리 분포하는 천연 항산화물질 
을 충분히 섭취하는 것은 항산화 시스템을 정상적으로 유지 하는데 도움이 되는 것으로 알려지면서(4,5) 천연 항산화제 에 대한 관심도 상승되었다. 특히 식물유래 생리활성 물질 로 널리 알려진 phenolic compounds, flavonoids 등은 신체 내에서 산화적 스트레스와 활성산소종의 생성을 억제하여 암, 심혈관계 질환 등 만성 질병을 예방하고 노화의 지연 및 방지에 도움이 되어 의약품, 화장품, 식품 등의 원료로 적극 활용되고 있다(2,4,6).

초석잠(Stachys sieboldii Miq)은 꿀풀과(Labiatae) 석잠풀 속(Stachy Linne) 식물로 여름에는 잎이 무성하고, 겨울에는 뿌리가 누에모양을 하고 있어 동충하초와 모양이 비슷하고 약효도 우수하여 식물의 동충하초라고 불리기도 하는데, 중국, 대만, 일본 등지에서 주로 재배되고 있다 $(5,7)$. 중국의 중약편에 의하면 초석잠은 뇌경색 예방, 기억력 증진 및 노인성 치매를 예방하며 장을 강화하는 장수채(長壽菜)로 서 옛날부터 애용해왔으며, 일본에서도 정월 요리에 귀하 게 쓰이기도 하고 여러가지 성인병과 만성병 치료에 유용하 게 쓰이기도 하였다(7). 초석잠은 탄수화물 중 올리고당의 일종인 stachyose에 기인하여 장내 기능 촉진 및 미생물 증식에 관여함으로써 면역력 강화와 배변작용 개선 등에 도움을 준다고 알려져 있다(8-10). 이 밖에도 초석잠의 효능 으로 항산화(11), 항암 및 면역(7), 항균(12), acetylcholinesterase 및 monoamine oxidase 활성억제 효과(13) 등이 보고되어 있다. 최근에 우리나라에서는 초석잠이 치매예방에 효과적 인 약용식물로 알려지게 되면서 그 재배면적이 점차 증가하 고 있지만(14,15) 현재까지 국내에 보고된 초석잠 관련 선행 연구들은 초석잠 분말을 첨가한 쌀머핀(16), 국수(17), 두부 (18), 식빵(19), 양갱(20) 및 수프(10) 등 가공식품 개발이 주를 이루고 초석잠의 기능성 성분 탐색에 관한 연구는 아직까지 미약한 실정이다.

따라서 본 연구에서는 다양한 초석잠의 기능성 탐색을 위한 기초연구의 일환으로 용매별 추출물을 제조하여 이들 추출물이 인체 내에서 여러 질병의 원인이 되는 산화작용의 억제 정도에 미치는 영향을 측정하고 부가적으로 항당뇨 활성 평가 지표인 a-amylase 및 a-glucosidase 저해활성을 측정하였다.

\section{재료 및 방법}

\author{
시료 및 추출물의 제조 \\ 실험에 사용된 초석잠은 경남 산청군의 동의초석잠영농 \\ 조합법인으로부터 초석잠 뿌리를 건조하여 분말화한 것을 \\ 제 공받았다. 초석잠의 용매 추출물은 건조 분말 $500 \mathrm{~g}$ 에 \\ 물, 에탄올, 부탄올, 클로로포름 및 헥산을 각각 $2 \mathrm{~L}$ 씩 가한 \\ 후 충분히 교반하여 상온에서 24시간 정치 추출한 다음 \\ 여과한 여액을 모아 회전식진공농축기(N-1200AVW, EYELA,
}

Tokyo, Japan)로 완전 건고한 것을 일정농도로 만들어 실험 에 사용하였다.

\section{총 폴리페놀 함량}

총 폴리페놀 화합물의 함량은 폴리페놀성 물질인 phosphomolybdic acid와 반응하여 청색을 나타내는 원리로 Folin-Denis법(21)에 따라 시료액 $1 \mathrm{~mL}$ 에 $2 \mathrm{M}$ FolinCiocalteau 시약(Sigma-Aldrich Co., St. Louis, MO, USA) $1 \mathrm{~mL}$ 를 넣고 3분 후 $10 \% \mathrm{Na}_{2} \mathrm{CO}_{3}$ (Daejung, Siheung, Korea) 용액 $1 \mathrm{~mL}$ 씩을 혼합하여 실온의 암실에서 1 시간 정치한 다음 분광광도계(Libra S 35, Biochrom, Cambridge, Cambridgeshire, England)를 이용하여 $760 \mathrm{~nm}$ 에서 흡광도 를 측정하였다. 표준물질로는 gallic acid(Sigma- Aldrich Co.)를 사용하여 시료와 동일한 방법으로 분석하여 얻은 검량선으로부터 총 폴리페놀 함량을 계산하였다.

\section{총 플라보노이드 함량}

총 플라보노이드 화합물 함량 분석은 Moreno 등(22)의 방법에 따라 시료액 $1 \mathrm{~mL}$ 에 $10 \%$ aluminum nitrate $0.1 \mathrm{~mL}$, $1 \mathrm{M}$ potassium acetate $0.1 \mathrm{~mL}$ 및 $80 \%$ 에탄올 $3.8 \mathrm{~mL}$ 를 차례로 가한 후 혼합하여 실온의 암실에서 40 분간 정치한 다음 분광광도계를 이용하여 $415 \mathrm{~nm}$ 에서 흡광도를 측정하 였다. Quercetin(Sigma-Aldrich Co.)을 표준물질로 하여 얻 은 검량선으로부터 총 플라보노이드 함량을 계산하였다.

\section{$\mathrm{DPPH}$ 라디칼 소거활성}

1,1-Diphenyl-2-picrylhydrazyl(DPPH) 라디칼 소거활성 은 Blois(23)의 방법을 응용하여 DPPH에 대한 전자공여 효과로 측정하였다. 즉, DPPH 용액 $(5 \mathrm{mg} / 100 \mathrm{~mL}$ 에탄올 $)$ $100 \mu \mathrm{L}$ 와 시료 $100 \mu \mathrm{L}$ 를 혼합한 다음 실온에서 20 분간 반응시킨 후 분광광도계를 이용하여 $525 \mathrm{~nm}$ 에서 흡광도를 측정하였다. DPPH 라디칼 소거활성(\%)은 시료 무첨가구 에 대한 시료첨가구의 흡광도비로 산출하였다.

\section{ABTS 라디칼 소거활성}

2,2-Azinobis-(3-ethylbenzo-thiazoline-6-sulphonate) (ABTS) 라디칼 소거활성은 $\operatorname{Re}$ 등(24)의 방법을 응용하여 $7 \mathrm{mM}$ 의 ABTS 용액에 potassium persulfate를 $2.4 \mathrm{mM}$ 이 되도록 용해시켜 암실에서 12-16시간 동안 반응시킨 후 $415 \mathrm{~nm}$ 에서 흡광도가 1.5 가 되도록 증류수로 조정한 ABTS 용액 $100 \mu \mathrm{L}$ 에 시료액 $100 \mu \mathrm{L}$ 를 혼합하고 실온에서 5 분간 반응시킨 다음 분광광도계를 이용하여 $415 \mathrm{~nm}$ 에서 흡광도 를 측정하였다. ABTS 라디칼 소거활성(\%)은 시료 무첨가 구에 대한 시료첨가구의 흡광도비로 산출하였다.

\section{Ferric reducing antioxidant power(FRAP)법에 의한 항산화 활성 측정}

초석잠 용매별 추출물 5 종에 대한 FRAP 측정은 Benzie 
와 Strain(25)의 방법에 따라 $\mathrm{pH} 3.6$ 의 $300 \mathrm{mM}$ acetate buffer, $40 \mathrm{mM} \mathrm{HCl}$ 에 용해한 $10 \mathrm{mM}$ TPTZ(2,4,6-tripyridyl-s-triazine) 용액 및 $20 \mathrm{mM} \mathrm{FeCl}_{3} \cdot 6 \mathrm{H}_{2} \mathrm{O}$ 를 각각 $10: 1: 1(\mathrm{v} / \mathrm{v} / \mathrm{v})$ 의 비율로 미리 혼합한 다음 $37^{\circ} \mathrm{C}$ 의 수욕상에서 5 분 동안 가온한 뒤 FRAP 측정용 기질로 사용하였다. 96 well plate에 시료액 $40 \mu \mathrm{L}, \mathrm{FRAP}$ 기질액 $100 \mu \mathrm{L}$ 및 증류수 $40 \mu \mathrm{L}$ 를 차례로 혼합하여 $37^{\circ} \mathrm{C}$ 에서 4 분간 반응시킨 후 $593 \mathrm{~nm}$ 에서 흡광도 를 측정하였으며, $\mathrm{FeSO}_{4}$ 로 작성한 검량식에 대입하여 환산 하였다

\section{$a-A m y l a s e$ 저해활성}

Pancreatin 기원의 a-amylase 저해활성은 시료액 $50 \mu \mathrm{L}$ 에 $1 \mathrm{unit} / \mathrm{mL}$ 의 a-amylase 효소액 $250 \mu \mathrm{L}$ 와 $50 \mathrm{mM}$ potassium phosphate buffer(pH 6.9) $250 \mu \mathrm{L}$ 를 혼합하여 $37^{\circ} \mathrm{C}$ 에서 10 분 간 반응시킨 후 $0.5 \% \operatorname{starch}$ 를 $500 \mu \mathrm{L}$ 가하여 다시 $37^{\circ} \mathrm{C}$ 에서 10 분간 반응시켰다. 반응액에 $48 \mathrm{mM} \mathrm{DNS}$ (3.5-dinitrosalicylic acid, $30 \%$ potassium sodium tartrate in $0.5 \mathrm{M} \mathrm{NaOH}$ ) 발색시 약 $500 \mu \mathrm{L}$ 를 넣고 $100^{\circ} \mathrm{C}$ 에서 15 분간 끓여 반응을 중지시킨 후 냉각하고 증류수를 $3 \mathrm{~mL}$ 을 가하여 희석시켰다. 이때 각 blank로는 효소액 첨가 후 기질을 넣기 전에 DNS 발색시 약을 먼저 넣은 것을 사용하였다. 반응액은 $540 \mathrm{~nm}$ 에서 흡광도를 측정하여 각 blank와의 차이를 구한 후 대조군과 비교하여 저해율을 계산하였다(26).

\section{a-Glucosidase 저해 활성}

a-Glucosidase 저해활성은 $0.1 \mathrm{M}$ phosphate 완충용액(pH 6.8)에 용해한 $2.5 \mathrm{mM}$ 의 p-nitrophenyl-a-D-glucopyranoside $50 \mu \mathrm{L}$ 와 $0.2 \mathrm{unit} / \mathrm{mL}$ 의 a-glucosidase $50 \mu \mathrm{L}$ 및 농도별 시료액 $50 \mu \mathrm{L}$ 를 혼합하여 $37^{\circ} \mathrm{C}$ 에서 20 분간 반응시킨 다음 $0.1 \mathrm{M}$ $\mathrm{NaOH} 100 \mu \mathrm{L}$ 로 반응을 정지시킨 후 $405 \mathrm{~nm}$ 에서 흡광도를 측정하였다. a-Glucosidase 저해활성은 효소액을 첨가하지 않은 실험구의 흡광도 및 시료 무첨가구의 흡광도를 각각 측정하여 그 비로부터 저해활성을 산출하였다(27).

\section{통계처리}

모든 실험은 3회 이상 반복하여 실시하였으며 실험으로 부터 얻은 결과는 SPSS statistics 18(IBM, Armonk, NY, USA) 통계 package를 이용하여 분석하였다. 결과는 평균 표준편차로 표시하였고, 통계적 유의성 검정은 변수 2 개의 시료군에 대한 분석은 대응표본 t-test를 통하여 평균차이 검증을 실시하였으며, 여타 시료들의 분석 결과는 일원배 치 분산분석을 한 후 $\mathrm{p}<0.05$ 수준에서 Duncan's multiple range test를 시행하였다.

\section{결과 및 고찰}

\section{총 폴리페놀 화합물 및 플라보노이드의 함량}

초석잠 용매별(물, 에탄올, 부탄올, 클로로포름 및 헥산)
추출물의 총 폴리페놀 화합물 및 플라보노이드 함량을 분석 한 결과는 Table 1 과 같다. 총 폴리페놀 화합물의 함량은 추출 용매에 따라 부탄올 > 에탄올 > 물 > 클로로포름 > 헥산 추출물의 순이었으며, 그 함량의 범위는 7.18-37.25 $\mathrm{mg} / \mathrm{g}$ 였다. 추출물 중 총 폴리페놀 화합물의 함량이 가장 높은 부탄올 추출물은 두 번째로 높은 에탄올 추출물보다 약 1.4 배, 가장 낮은 헥산 추출물보다는 약 5.2 배 더 높은 함량이었다. 초석잠 뿌리 분말의 에탄올 추출물은 총 폴리 페놀 함량이 $20.44 \mathrm{mg} / \mathrm{g}$ 으로 보고되어져 있는데(15), 이는 본 연구의 에탄올 추출물에 함유된 $26.24 \mathrm{mg} / \mathrm{g}$ 과 큰 차이가 없었다.

총 플라보노이드 함량은 $0.21-5.21 \mathrm{mg} / \mathrm{g}$ 의 범위였으며, 이 또한 부탄올 > 에탄올 > 물 > 클로로포름 > 헥산 추출물 의 순으로 총 폴리페놀 화합물의 함유 경향과 일치하였다. 추출물 중 플라보노이드 함량이 가장 높은 부탄올 추출물과 가장 함량이 낮은 헥산 추출물 간의 함량 차이는 약 24.8 배 로 추출용매에 따라 플라보노이드 용출량에 큰 차이가 있었 다.

머루 과피를 용매별로 추출하여 폴리페놀 및 플라보노이 드 함량을 측정한 결과에서도 본 연구와 같이 부탄올 추출 물이 헥산, 클로로포름 및 물 추출물보다 함량이 더 높았다 고 보고되어 있다(28). 또한 복숭아꽃 에탄올 추출물과 분획 물의 총 폴리페놀 함량은 부탄올 > 에탄올 > 물 > 헥산 분획물의 순이었다고 보고되었는데(29) 이들 결과들은 본 연구의 결과와 유사하였다.

폴리페놀 화합물의 phenol hydroxyl기는 자유라디칼과 결합하여 안정화된 공명구조의 phenoxy radical을 형성하여 직접적으로 자유라디칼들을 소거하거나, 항산화 효소와 함 께 간접적으로 자유 라디칼을 제거함으로써 항산화 효과, 간 보호 작용, 항암 및 항균 등의 생리활성 기능을 가진다 (30). 초석잠으로부터 플라보노이드를 비롯한 폴리페놀 화 합물의 함량이 더 높아 상대적으로 생리활성이 더 높은 추출물을 얻기 위해서는 부탄올과 에탄올을 추출용매로 사용하는 것이 유리할 것으로 판단된다.

Table 1. Total polyphenol and flavonoid contents of extracts from Stachys sieboldii Miq.

\begin{tabular}{ccc} 
& & \\
\hline Extraction solvent & Total polyphenols & Flavonoids \\
\hline Water & $10.03 \pm 0.08^{1)(\mathrm{c} 2)}$ & $0.63 \pm 0.01^{\mathrm{c}}$ \\
Ethanol & $26.24 \pm 0.34^{\mathrm{d}}$ & $3.22 \pm 0.07^{\mathrm{d}}$ \\
Butanol & $37.25 \pm 0.49^{\mathrm{e}}$ & $5.21 \pm 0.08^{\mathrm{e}}$ \\
Chloroform & $9.30 \pm 0.31^{\mathrm{b}}$ & $0.49 \pm 0.03^{\mathrm{b}}$ \\
Hexane & $7.18 \pm 0.13^{\mathrm{a}}$ & $0.21 \pm 0.01^{\mathrm{a}}$ \\
\hline
\end{tabular}

${ }^{1)}$ All values are mean \pm SD $(n=3)$.

2)a-e Means with different superscripts within the same column are significantly different by Duncan's multiple range test $(\mathrm{p}<0.05)$. 


\section{$\mathrm{DPPH}$ 라디칼 소거활성}

초석잠 용매별 추출물의 DPPH 라디칼 소거활성은 용매 별 추출물을 각각 $500,1,000$ 및 $2,000 \mathrm{\mu g} / \mathrm{mL}$ 의 농도로 제조 한 후 시료와 동량의 DPPH 용액을 혼합하여 반응시킨 다음 라디칼 소거활성 정도를 \%로 나타내었다(Table 2). 모든 추출물에서 DPPH 라디칼 소거활성이 농도 의존적으로 유 의하게 증가하였으나 농도에 따른 활성의 변화 경향은 추출 용매에 따라 서로 상이하였다. 즉, $500 \mu \mathrm{gg} / \mathrm{mL}$ 에서 부탄올 추출물의 활성은 $77.34 \%$ 로 가장 높았으며, 다음으로 에탄 올 추출물의 활성은 $42.78 \%$ 였고, 헥산이나 물 추출물의 경우 활성이 매우 낮아 $10 \%$ 미만에 불과하였다. $2,000 \mu$ $\mathrm{g} / \mathrm{mL}$ 농도에서는 부탄올 추출물 보다는 에탄올 추출물의 활성이 유의적으로 더 높아 $87.05 \%$ 였고 그 외 추출물들에 서는 시료의 농도가 증가함에 따라 활성이 증가하는 경향이 었으나 활성은 $30 \%$ 미만으로 낮았다.

석류 내피 용매별 추출물의 DPPH 라디칼 소거활성을 측정한 결과, 부탄올 층과 물 층의 $\mathrm{IC}_{50}$ 값은 각각 40.95 $\mu \mathrm{g} / \mathrm{mL}$ 과 $253.01 \mu \mathrm{g} / \mathrm{mL}$ 로 부탄올 층이 물 층보다 $\mathrm{DPPH}$ 라디칼 소거활성이 더 우수한 것으로 보고된 바 있고(31), 와송 용매별 분획물의 DPPH 라디칼 소거활성 또한 부탄올, 헥산, 물 층 순으로 높았다고 보고되어 있다(32). DPPH 법으로 용매별 머루 과피 추출물의 전자공여능을 측정한 결과(28)에서는 시료가 $1,000 \mathrm{\mu g} / \mathrm{mL}$ 농도일 때 전자공여능 은 부탄올, 헥산, 물, 클로로포름 추출물의 순인 것으로 나타 났다. 상기의 결과들과 본 연구결과를 비교해보면 용매별 추출물의 DPPH 라디칼 소거활성은 시료에 따라 그 활성 경향이 차이를 보이지만 일반적으로 부탄올 추출물이 여타 의 용매 추출물보다는 활성이 더 높은 동일한 경향이었다.

Table 2. DPPH radical scavenging activity of extracts from Stachys sieboldii Miq.

$(\%)$

\begin{tabular}{cccc}
\hline \multirow{2}{*}{ Extraction solvent } & \multicolumn{3}{c}{ Concentration $(\mu \mathrm{g} / \mathrm{mL})$} \\
\cline { 2 - 4 } & 500 & 1,000 & 2,000 \\
\hline Water & $5.06 \pm 0.20^{1 \mathrm{l} 2 \mathrm{a}) \mathrm{A} 3)}$ & $17.47 \pm 0.15^{\mathrm{bB}}$ & $29.34 \pm 0.42^{\mathrm{CC}}$ \\
Ethanol & $42.78 \pm 0.82^{\mathrm{dA}}$ & $79.78 \pm 0.69^{\mathrm{dB}}$ & $87.05 \pm 0.76^{\mathrm{CC}}$ \\
Butanol & $77.34 \pm 0.88^{\mathrm{eA}}$ & $78.53 \pm 1.55^{\mathrm{dAB}}$ & $81.11 \pm 1.35^{\mathrm{dB}}$ \\
Chloroform & $15.41 \pm 0.46^{\mathrm{CA}}$ & $20.99 \pm 0.70^{\mathrm{cB}}$ & $21.66 \pm 1.43^{\mathrm{aB}}$ \\
Hexane & $8.92 \pm 0.44^{\mathrm{bA}}$ & $11.50 \pm 0.56^{\mathrm{aB}}$ & $24.18 \pm 0.80^{\mathrm{bC}}$ \\
\hline
\end{tabular}

${ }^{1)}$ All values are mean \pm SD ( $\left.n=3\right)$.

${ }^{2) a-d}$ Means with different superscript small letters within the same concentration are significantly different by Duncan's multiple range test $(p<0.05)$.

3)A-E Means with different superscript capital letters within the same extraction solvent are significantly different by Duncan's multiple range test $(p<0.05)$.

\section{ABTS 라디칼 소거활성}

Table 3은 초석잠 용매별 추출물의 ABTS 라디칼 소거활 성을 분석한 결과이다. 시료의 농도가 높을수록 라디칼 소
거활성은 증가하는 경향이었으며, 추출용매에 따라 활성에 도 차이가 있었다. 부탄올과 에탄올 추출물의 ABTS 라디칼 소거활성이 여타 시료에 비해 유의적으로 높아 $500 \mu \mathrm{g} / \mathrm{mL}$ 농도에서 각각 $97.99 \%$ 와 $96.52 \%$ 였다. 이들을 제외한 물, 클로로포름 및 헥산 추출물들의 ABTS 라디칼 소거활성은 실험된 모든 농도에서 물 > 클로로포름 > 헥산 추출물 순이 었으며, 농도가 높아질수록 물 추출물과 클로로포름 및 헥 산 추출물의 활성 차가 더 커졌다. 즉, $500 \mu \mathrm{g} / \mathrm{mL}$ 농도에서 물 추출물에 대한 클로로포름 및 헥산 추출물의 활성의 차는 각각 $5.65 \%$ 와 $9.82 \%$ 이던 것이 $2,000 \mu \mathrm{gg} / \mathrm{mL}$ 에서는 차이가 더 커져 각각 $17.39 \%$ 와 $20.13 \%$ 였다.

초석잠 용매별 추출물의 DPPH 및 $\mathrm{ABTS}$ 라디칼 소거활 성 모두 부탄올 > 에탄올 > 물 > 클로로포름 > 헥산 추출물 의 순으로 활성이 높았다. 그러나 $\mathrm{ABTS}$ 법으로 측정한 값들 이 $\mathrm{DPPH}$ 법으로 측정하였을 때 보다 전체적으로 더 높았다. 이러한 차이는 각각의 라디칼이 활성을 나타내는 기작이 서로 상이하기 때문으로 생각되는데, DPPH 라디칼 소거활 성과 ABTS 라디칼 소거활성은 각 방법에서 이용되는 라디 칼의 종류가 다르고, 페놀물질의 종류에 따라 두 기질에 결합하는 정도의 차이와 라디칼을 제거하는 능력이 다른 것으로 보고되어 있다 $(33,34)$.

일반적으로 폴리페놀 화합물 함량에 기인하여 식물체들 이 항산화 활성을 보이는 것으로 알려져 있지만(30) 이 외에 영양성분인 비타민 $\mathrm{C}$ 와 $\mathrm{E}$ 도 세포의 활성산소를 제거하여 산화적 스트레스를 완화시키는 기작으로 항산화 활성에 긍정적으로 영향을 주는 것으로 보고되어 있다(35). 수용성 비타민의 일종인 비타민 $\mathrm{C}$ 는 주로 수용성 환경에서 강한 생물학적 환원제로 쓰이는 항산화 기능을 가지고, 비타민 $\mathrm{E}$ 는 자유라디칼 생성을 억제시켜 피부 탄력섬유의 색소침 착과 손상을 억제시키는 것으로 알려져 있다(35). 초석잠의 부위별 영양성분을 측정한 결과(15), 잎 분말은 비타민 $\mathrm{E}$ 를 $11.49 \mathrm{mg} \%$ 함유하고 있고 뿌리 분말은 비타민 C를 255.76

Table 3. ABTS radical scavenging activity of extracts from Stachys sieboldii Miq.

\begin{tabular}{cccc}
\hline \multirow{2}{*}{ Extraction solvent } & \multicolumn{3}{c}{ Concentration $(\mu \mathrm{g} / \mathrm{mL})$} \\
\cline { 2 - 4 } & 500 & 1,000 & 2,000 \\
\hline Water & $28.73 \pm 0.41^{1 \mathrm{cc} 2) \mathrm{A} 3)}$ & $49.20 \pm 0.70^{\mathrm{cB}}$ & $83.63 \pm 0.23^{\mathrm{CC}}$ \\
Ethanol & $96.52 \pm 0.08^{\mathrm{dA}}$ & $97.79 \pm 0.05^{\mathrm{dB}}$ & $97.99 \pm 0.02^{\mathrm{dC}}$ \\
Butanol & $97.99 \pm 0.21^{\mathrm{eA}}$ & $98.39 \pm 0.18^{\mathrm{dAB}}$ & $98.64 \pm 0.22^{\mathrm{dB}}$ \\
Chloroform & $23.08 \pm 0.33^{\mathrm{bA}}$ & $39.72 \pm 0.78^{\mathrm{bB}}$ & $66.24 \pm 1.50^{\mathrm{bC}}$ \\
Hexane & $18.91 \pm 0.19^{\mathrm{aA}}$ & $34.30 \pm 0.42^{\mathrm{aB}}$ & $63.50 \pm 0.34^{\mathrm{aC}}$ \\
\hline
\end{tabular}

${ }^{11}$ All values are mean $\pm \mathrm{SD}(\mathrm{n}=3)$.

2)a-d Means with different superscript small letters within the same concentration are significantly different by Duncan's multiple range test $(p<0.05)$.

${ }_{3 A-}$ Means with different superscript capital letters within the same extraction solvent are significantly different by Duncan's multiple range test $(p<0.05)$. 
$\mathrm{mg} \%$ 다량 함유하고 있다고 보고하였다. 이러한 보고들로 부터 미루어 볼 때 본 연구의 초석잠 용매별 추출물의 항산 화 활성은 플라보노이드를 비롯한 폴리페놀 화합물 외에도 항산화 비타민류와 같은 기능성 성분들이 복합적으로 작용 하여 나타난 결과로 추정된다.

\section{FRAP법에 의한 항산화활성}

FRAP에 의한 환원력 실험은 금속이온인자 $\left(\mathrm{Fe}^{2+}\right.$ 등 $)$ 에 대한 킬레이트 활성이 높을수록 산화 반응에서 촉매작용을 감소시켜 항산화 활성을 보이고 높은 환원력을 가지는 물질 은 흡광도의 수치가 높게 나타나는 원리를 이용해 항산화 활성을 평가하는 방법이다(25).

각각 $500,1,000$ 및 $2,000 \mathrm{\mu g} / \mathrm{mL}$ 로 농도 조절한 초석잠 용매별 추출물의 FRAP는 Table 4와 같다. FRAP는 여타 항산화 실험 결과와 같이 시료의 첨가 농도가 증가함에 따라 활성도 유의적으로 높아졌다. 추출 용매에 따라서는 모든 농도에서 부탄올 > 에탄올 > 헥산 > 클로로포름 > 물 추출물의 순이었다. 시료 추출물 중 FRAP 값이 가장 높은 부탄올 추출물은 $500 \mu \mathrm{g} / \mathrm{mL}$ 농도에서 $89.25 \mu \mathrm{M}$ 이었는 데, 이는 다음으로 활성이 높은 에탄올 $(44.86 \mu \mathrm{M})$ 추출물에 비해서도 2 배 이상 활성이 더 높았다. 가장 활성이 낮은 물 추출물의 경우 시료의 농도가 가장 높은 $2,000 \mathrm{\mu g} / \mathrm{mL}$ 농도에서도 활성은 $30 \mu \mathrm{M}$ 미만이었다.

FRAP 법과 DPPH 법은 높은 상관관계를 나타낸다고 보 고되어 있으나(36) 본 연구에서 FRAP 값은 물 추출물이 클로로포름과 헥산 추출물보다 더 낮은 값을 보여 $\mathrm{DPPH}$ 라디칼 소거활성 경향과 다소 차이가 있었다. 로즈마리 분 획물의 항산화 활성 측정 결과(37)에서는 부탄올 분획물의 FRAP 값은 헥산, 물 및 클로로포름 분획물보다 월등히 높 은 것으로 보고되었는데, 이는 본 연구와도 일치하는 경향 이었으며, FRAP 법에 의한 항산화 활성 역시 부탄올 추출 물이 다른 용매 추출물보다 더 높았다.

초석잠과 인삼 분말의 항산화 활성을 비교한 결과(38), 초석잠이 인삼보다 DPPH 라디칼 소거능은 16.83 배, FRAP 는 3.39배, trolox equivalent antioxidant capacity(TEAC)는 3.18 배 유의적으로 높았으며, 이는 초석잠에 함유된 총 폴 리페놀 화합물이 인삼에 비해 3.12배나 더 높기 때문이라고 보고하였다. 초석잠과 같은 천연식물의 항산화 활성과 관 련하여 활성 물질 규명을 위한 연구들이 진행되고 있는데, 초석잠의 계통분획물 중 항산화 활성이 높은 에틸아세테이 트와 부탄올 분획물은 BHT에 비해서도 더 활성이 높았고 이는 flavone 계통의 폴리페놀 화합물에 의한 효능이라는 보고도 있다(11). 또한, 초석잠의 계통 분획물로부터 신규 화합물 19 종을 분리하였는데, 이들 화합물의 다수가 항염, 항알러지, 항산화, 항돌연변이 등 다양한 약리활성을 가지 는 triterpenoid 유도체에 속하는 oleanoic acid와 ursolic acid 의 유도체 물질들이라고 보고된 바 있다(39).
Table 4. Ferric reducing antioxidant power (FRAP) of extracts from Stachys sieboldii Miq.

\begin{tabular}{cccc} 
& \multicolumn{3}{c}{$\left(\mathrm{FeSO}_{4} \cdot 7 \mathrm{H}_{2} \mathrm{O}\right.$ eq $\left.\mu \mathrm{M}\right)$} \\
\hline \multirow{2}{*}{ Extraction solvent } & \multicolumn{3}{c}{ Concentration $(\mu \mathrm{g} / \mathrm{mL})$} \\
\cline { 2 - 4 } & 500 & 1,000 & 2,000 \\
\hline Water & $2.70 \pm 0.22^{1 \mathrm{1}) 2 \mathrm{~A}) \mathrm{A} 3)}$ & $10.82 \pm 1.02^{\mathrm{aB}}$ & $27.97 \pm 0.42^{\mathrm{aC}}$ \\
Ethanol & $44.86 \pm 0.62^{\mathrm{dA}}$ & $92.97 \pm 0.74^{\mathrm{dB}}$ & $184.03 \pm 0.82^{\mathrm{dC}}$ \\
Butanol & $89.25 \pm 0.83^{\mathrm{eA}}$ & $188.48 \pm 1.48^{\mathrm{eB}}$ & $322.90 \pm 0.24^{\mathrm{eC}}$ \\
Chloroform & $13.14 \pm 0.31^{\mathrm{bA}}$ & $31.76 \pm 1.07^{\mathrm{BB}}$ & $56.00 \pm 1.09^{\mathrm{bC}}$ \\
Hexane & $15.00 \pm 0.26^{\mathrm{CA}}$ & $36.38 \pm 0.58^{\mathrm{CB}}$ & $63.98 \pm 0.69^{\mathrm{CC}}$ \\
\hline
\end{tabular}

${ }^{1)}$ All values are mean \pm SD $(n=3)$.

${ }^{2) a-d}$ Means with different superscript small letters within the same concentration are significantly different by Duncan's multiple range test $(p<0.05)$.

3)A-c Means with different superscript capital letters within the same extraction solvent are significantly different by Duncan's multiple range test $(\mathrm{p}<0.05)$.

\section{a-Amylase 저해활성}

a-Amylase는 탄수화물의 a-D-(1,4)-glucan 결합을 분해 하며 사람, 동물, 미생물, 곤충 등의 탄수화물 대사에 필수적 인 효소로(40) 활성이 저해될 경우 식사를 통해서 체내로 들어온 전분이 덜 분해되어 혈중으로 유리되는 혈당의 양이 감소하게 됨으로써 전체적인 에너지 흡수를 저해하는 기초 역할을 하게 된다(41,42). 그러나 당뇨, 비만, 과혈당증 등 탄수화물과 관련된 질병치료를 위한 식물체를 대상으로 한 연구에서 a-amylase 저해제에 대한 보고는 미흡한 실정 이다 $(40,43)$.

초석잠 용매별 추출물을 이용하여 a-amylase 저해활성을 측정한 결과(Table 5), $1,000 \mu \mathrm{g} / \mathrm{mL}$ 과 $2,000 \mu \mathrm{g} / \mathrm{mL}$ 의 농도에 서 모든 용매별 초석잠 추출물은 효소의 활성을 저해하지 못하고 오히려 촉진하였는데 $1,000 \mu \mathrm{gg} / \mathrm{mL}$ 농도에서는 $113.74-127.00 \%$ 의 범위였다. $2,000 \mu \mathrm{g} / \mathrm{mL}$ 농도에서는 $106.34-137.62 \%$ 의 활성을 나타내었는데, 부탄올 추출물의 경우 농도에 따른 활성에 유의차가 없었으며, 에탄올과 클

Table 5. a-Amylase inhibition activity of extracts from Stachys sieboldii Miq.

$(\%)$

\begin{tabular}{ccc}
\hline \multirow{2}{*}{ Extraction solvent } & \multicolumn{2}{c}{ Concentration $(\mu \mathrm{g} / \mathrm{mL})$} \\
\cline { 2 - 3 } & 1,000 & 2,000 \\
\hline Water & $120.47 \pm 1.17^{1162) * 3)}$ & $117.64 \pm 0.68^{\mathrm{b}}$ \\
Ethanol & $127.00 \pm 1.47^{\mathrm{c}}$ & $137.62 \pm 1.47^{\mathrm{e}^{*}}$ \\
Butanol & $121.44 \pm 0.89^{\mathrm{b}}$ & $120.66 \pm 0.68^{\mathrm{c}}$ \\
Chloroform & $120.37 \pm 1.35^{\mathrm{b}}$ & $127.10 \pm 1.22^{\mathrm{d}^{*}}$ \\
Hexane & $113.74 \pm 0.58^{\mathrm{a}^{*}}$ & $106.34 \pm 0.34^{\mathrm{a}}$ \\
\hline
\end{tabular}

${ }^{1)}$ All values are mean $\pm \mathrm{SD}(\mathrm{n}=3)$.

${ }^{2) a-d}$ Means with different superscript small letters within the same concentration are significantly different by Duncan's multiple range test $(p<0.05)$.

${ }^{3)}$ Means with different superscript within the same extraction solvent are significantly different by independent $t$-test $(p<0.05)$. 
로로포름 추출물의 경우 시료의 농도가 높을 때 활성도 더 증가하였으나 물과 헥산 추출물에서는 이와 상반된 경향 이었다.

\section{a-Glucosidase 저해활성}

a-Glucosidase는 소장 탄수화물 소화의 마지막 단계에서 이당류를 가수분해하는 효소로(44) a-amylase에 의해 분해 된 당질을 최종적으로 단당류로 전환시키는 것으로 알려져 있다(45). 따라서 효소에 대한 저해능은 탄수화물 섭취 후 혈당상승을 억제할 수 있어 항당뇨 활성측정의 지표로 이용 된다(44).

초석잠 용매별 추출물을 $250,500,1,000$ 및 $2,000 \mu \mathrm{gg} / \mathrm{mL}$ 범위로 제조한 후 a-glucosidase 저해활성을 분석한 결과는 Table 6과 같다. 모든 농도에서 a-glucosidase 저해활성이 없었던 물 추출물을 제외하고는 시료의 농도가 증가할수록 활성도 증가함을 확인할 수 있었다. 헥산 추출물의 $a$ -glucosidase 저해활성이 시료군 중 가장 높은 경향으로 가 장 낮은 농도인 $250 \mathrm{\mu g} / \mathrm{mL}$ 농도에서도 활성이 $57.76 \%$ 로 가장 높아 다음으로 활성이 높은 클로로포름 추출물 (20.65\%)에 비해 약 2.7 배 더 활성이 높았다. 부탄올과 에탄 올 추출물의 경우 $250 \mathrm{\mu g} / \mathrm{mL}$ 농도에서 a-glucosidase 저해활 성은 클로로포름 추출물보다 더 낮았으나 $1,000 \mu \mathrm{g} / \mathrm{mL}$ 농 도에서 활성은 각각 $46.46 \%$ 와 $47.47 \%$ 로 클로로포름 추출 물(43.75\%)보다 유의적으로 활성이 높았다. $2,000 \mu \mathrm{gg} / \mathrm{mL}$ 농도에서 a-glucosidase 저해활성은 물과 클로로포름 (51.18\%) 추출물을 제외하고 여타의 추출물들은 모두 $65 \%$ 이상의 활성을 보였다.

본 연구에서 초석잠 용매별 추출물들은 a-amylase 효소 의 활성은 저해하지 않고 오히려 촉진하는 결과를 나타내었 지만 당질을 최종적으로 단당류로 전환시키는 효소인 a -glucosidase의 활성은 효과적으로 저해하여 최종적으로 항 당뇨 작용에 기여할 것으로 사료된다.

일반적으로 폴리페놀과 사포닌계 화합물이 a-glucosidase 효소 활성 저해에 관여하고, vanillic acid, p-hydroxybenzaldehyde 과 같은 phenolic acid계 및 플라보노이드계 화합물이 항산 화 효과뿐 아니라 a-glucosidase 저해활성과도 높은 상관관 계를 가지는 것으로 보고되어 있으나 $(46,47)$ 식물류의 폴리 페놀 및 플라보노이드 물질은 구조적 특징에 따라 항당뇨 활성에 차이를 보이는 것으로 알려져 있다 $(48,49)$.

본 연구의 결과에서 초석잠 용매별 추출물들의 총 폴리 페놀 및 플라보노이드 화합물 함량은 부탄올 및 에탄올 추출물이 여타 추출물에 비해 더 높았으나 a-glucosidase 저해활성은 항산화 활성이 상대적으로 낮았던 헥산 추출물 에서 더 높았는데 이는 이들 추출물 중에 함유되어 있는 페놀 및 플라보노이드 화합물의 구조가 서로 상이하기 때문 으로 추정된다.
Table 6. a-Glucosidase inhibition activity of extracts from Stachys sieboldii Miq.

$(\%)$

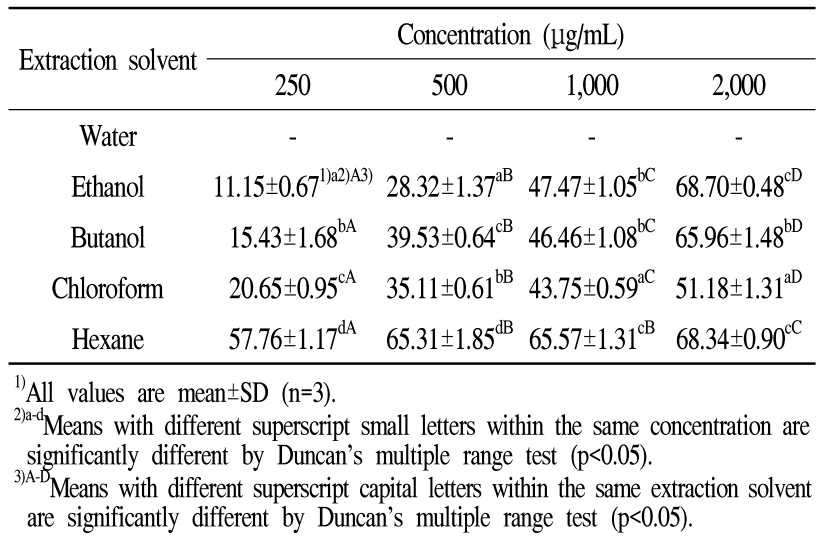

\section{요 약}

본 연구에서는 초석잠 뿌리의 용매별(물, 에탄올, 부탄올, 클로로포름 및 헥산) 추출물을 제조한 후 항산화와 항당뇨 활성을 측정하여 초석잠의 생리활성 규명을 위한 기초자료 를 확보하고자 하였다. 추출물들의 총 폴리페놀 화합물 $(7.18-37.25 \mathrm{mg} / \mathrm{g})$ 및 플라보노이드(0.21-5.21 mg/g) 함량은 부탄올 > 에탄올 > 물 > 클로로포름 > 헥산 추출물의 순으로 추출 용매에 따라 차이가 있었다. DPPH 및 ABTS 라디칼 소거활성을 통한 항산화 활성은 농도 의존적으로 증가하였 고, 추출 용매에 따른 활성의 절대 값은 서로 상이하였으나 폴리페놀성 화합물의 함량이 높을수록 활성도 더 높은 경향 이었다. FRAP법에 의한 항산화 활성 또한 농도 의존적으로 유의하게 증가하였으나 모든 농도에서 부탄올 > 에탄올 > 헥산 > 클로로포름 > 물 추출물의 순으로 DPPH 및 ABTS 라디칼 소거활성 활성과는 차이가 있었다. a-Amylase 저해 활성은 실험된 $1,000 \mu \mathrm{gg} / \mathrm{mL}$ 과 $2,000 \mu \mathrm{\mu g} / \mathrm{mL}$ 의 농도에서 모 든 용매별 초석잠 추출물은 효소의 활성을 저해하지 못하고 오히려 촉진하였다. a-Glucosidase 저해활성은 물 추출물은 모든 농도에서 활성이 없었으며, 그 외 추출물에서는 시료 의 농도가 증가할수록 활성도 증가함을 확인할 수 있었다. 항산화 활성과는 다르게 전반적으로 헥산 추출물의 활성이 부탄올과 에탄올 추출물보다 높았다. 이상의 결과를 종합 하여 볼 때 초석잠은 추출용매에 따라 용출되는 유효성분이 서로 상이하여 이들의 주요 작용기가 나타내는 활성에도 차이를 나타내는 것으로 추정되므로 각 추출 용매별 유효성 분의 규명에 관한 연구가 차후에 더 진행되어야 할 것이다.

\section{감사의 글}

경상남도 항노화산업 육성 지원사업의 미래 선도기술 
산업화 지원과제(B20164031) 연구성과의 일부이며 연구비 지원에 감사드립니다.

\section{References}

1. Yeo JS, Chun SS, Choi JH (2014) Antioxidant activities of solvent extracts from Rosa multiflora. J Life Sci, 24, 1217-1223

2. Kang DH, Park EM, Kim JH, Yang JW, Kim JH, Kim MY (2016) Bioactive compounds and antioxidant activity of Jeju camellia mistletoe (Korthalsella japonica Engl.), J Life Sci, 26, 1074-1081

3. Valko M, Leibfritz D, Moncol J, Cronin MTD, Mazur M, Telser J (2007) Free radicals and antioxidants in normal physiological functions and human disease. Int J Biochem Cell Biol, 39, 44-84

4. Kim EJ, Choi JY, Yu MR, Kim MY, Lee SH, Lee BH (2012) Total polyphenols, total flavonoid contents, and antioxidant activity of Korean natural and medicinal plants. Korean J Food Sci Technol, 44, 337-342

5. Jeon KS, Park SI (2015) Antioxidative properties of Chinese artichoke (Stachys sieboldii Miq) added white bread. Korean J Culinary Res, 21, 120-132

6. Lee JY, Ko SH, Mun SJ, You JH, Kim SW (2013) Investigation of forest therapeutic function according to the antioxidant activity and total phenolics in magnoliaceae flower. J Korea Institute Forest Reaction, 17, 81-86

7. Ryu BH, Park BG, Song SK (2002) Antitumor effects of the hexane extract of Stachys sieboldii MIQ. Korean J Biotechnol Bioeng, 17, 520-524

8. Yin J, Yang G, Wang S, Chen Y (2006) Purification and determination of stachyose in Chinese artichoke (Stachys sieboldii Miq.) by high-performance liquid chromatography with evaporative light scattering detection. Talanta, 70, 208-212

9. Masai T, Wada K, Hayakawa K, Yoshihara I, Mitsuoka $\mathrm{T}$ (1987) Effects of soybean oligosaccharides on human intestinal flora and metabolic activities. Japan J Bacteriol, 42, 313-315

10. Tae MH, Kim KH, Yook HS (2016) Physicochemical and sensory properties of soup added with Stachys sieboldii Miq root powder. J Korean Soc Food Sci Nutr, 45, 557-561

11. Baek HS, Na YS, Kim DH, Lee CH, Ryu BH, Song SK (2004) Antioxidant activities of Stachys sieboldii MIQ roots. J Life Sci, 14, 1-7

12. Ryu BH, Park BG (2002) Antimicrobial activity of the hexane extract of Stachys sieboldii MIQ leaf. Korean J Life Sci 12, 803-811

13. Ryu BH, Kim SO (2004) Effects of methanol extract of Stachys sieboldii MIQ on acetylcholine esterase and monoamine oxidase in rat brain. Korean J Food Nutr, $17,347-355$

14. Lee SW, Jung TH, Shin YW (2013) A comparative study of memory improving effects of Stachys rhizome and Lycopi thizome on scopolamine-induced amnesia in mice. Kor J Herbol, 28, 69-77

15. Kim YK, Son HK, Lee JJ (2017) Nutritional components and antioxidant activities of various Stachys sieboldii Miq parts. Korean J Community Living Sci, 28, 203-215

16. Chung MJ, Lee SM, Joo NM (2014) Optimization of rice cookies prepared with Chinese artichoke (Stachys sieboldii Miq) powder using response surface methodology and quality characteristics. Korean J Food Nutr, 27, 435-446

17. Park EJ (2017) Quality characteristics and antioxidant activity of noodles added with Chinese artichoke powder. J East Asian Soc Diet Life, 27, 61-68

18. Lee JE, Jin SY, Han YS (2014) Antioxidant activities and quality characteristics of Tofu supplemented with Chinese artichoke powder. Korean J Food Nutr, 27, 10-21

19. Jeon KS, Lee NH, Park SI (2015) Quality characteristics of white pan bread with Chinese artichoke (Stachys sieboldii MIQ) powder. Korean J Culinary Res, 21, 1-15

20. Choi SH (2016) Quality characteristics of Yanggaeng added with Chinese artichoke (Stachys sieboldii Miq) powder. Culinary Sci Hosp Res, 22, 99-108

21. Folin O, Denis W (1912) On phosphotungstic-phosphomolybdic compounds as color reagents. J Biol Chem, 12, 239-243

22. Moreno MI, Isla MI, Sampietro AR, Vattuone MA (2000) Comparison of the free radical-scavenging activity of propolis from several regions of Argentina. J ethnopharmacol, 71, 109-114

23. Blois MS (1958) Antioxidant determinations by the use of a stable free radical. Nature, 181, 1199-1200

24. Re R, Pellegrini N, Proteggente A, Pannala A, Yang M, Rice-Evans C (1999) Antioxidant activity applying an improved ABTS radical cation decolorization assay. Free Radical Biol Med, 26, 1231-1237

25. Benzie IFF, Strain JJ (1996) The ferric reducing ability of plasma (FRAP) as a measure of "antioxidant power": 
The FRAP assay. Anal Biochem, 239, 70-76

26. Gao H, Kawabata J (2005) a-Glucosidase inhibition of 6-hydroxyflavones. Part 3: Synthesis and evaluation of 2,3,4-trihydroxybenzoyl-containing flavonoid analogs and 6-aminoflavones as a-glucosidase inbibitors. Bioorg Med Chem, 13, 1661-1671

27. Matsui $T$, Ueda $T$, Oki $T$, Sugita $K$, Terahara $N$, Matsumoto K (2001) a-Glucosidase inhibitory action of natural acylated anthocyanins 1. Survey of natural pigments with potent inhibitory activity. J Agric Food Chem, 49, 1948-1951

28. Park HS (2011) Antioxidant activity of solvent extracts from Vitis coignetiea skins. Korean J Culinary Res, 17, 208-217

29. Kwak CS, Choi HI (2015) In vitro antioxidant and anti-Inflammatory activities of ethanol extract and sequential fractions of flowers of Prunus persica in LPS-stimulated RAW 264.7 macrophages. J Korean Soc Food Sci Nutr, 44, 1439-1449

30. Lee JH, Lee SR (1994) Some physiological activity of phenolic substances in plant foods. Korean J Food Sci Technol, 26, 317-323

31. Jin SY (2011) Antioxidant activities of solvent extracts from pomegranate endocarp. J Korean Soc Food Sci Nutr, 40, 1635-1641

32. Kim SM, Park JH, Boo HO, Song SG, Park HY (2017) In vitro comparision of biological activities of solvent fraction extracts from Orostachys japonicus. Korean J Plant Res, 30, 133-143

33. Wang M, Li J, Rangarajan M, Shao Y, LaVoie EJ, Huang TC, Ho CT (1998) Antioxidative phenolic compounds from sage (Salvia officinalis). J Agric Food Chem, 46, 4869-4873

34. Hyun MR, Lee YS, Park YH (2011) Antioxidative activity and flavonoid content of Chrysanthemum zawadskii flowers. Kor J Hort Sci Technol, 29, 68-73

35. Hong JK (2009) A Study on skin aging caused by free-radical and on efficacy of antioxidant vitamins. Kor J Aesthet Cosmetol, 7, 51-62

36. Moon GS, Ryu BM, Lee MJ (2003) Components and antioxidative activities of Buchu (Chinese chives) harvested at different times. Korean J Food Sci Technol, 35, 493-498

37. Yu MH, Chae IG, Jung YT, Jeong YS, Kim HI, Lee IS (2011) Antioxidative and antimicrobial activities of methanol extract from Rosmarinus officinalis L. and their fractions. J Life Sci, 21, 375-384
38. Na BR, Lee JH (2017) Antioxidative capacities of Stachys sieboldii MIQ and ginseng powders and their effects on quality characteristics of cookies. J Korean Soc Food Sci Nutr, 46, 68-76

39. Cho HK (2013) Phytochemical constituents from the tubers of Stachys sieboldii MIQ.. MS Thesis, Sungkyunkwan University, Korea, p 144-145

40. Lee BB, Park SR, Han CS, Han DY, Park EJ, Park HR, Lee SC (2008) Antioxidant activity and inhibition activity against a-amylase and a-glucosidase of Viola mandshurica extracts. J Korean Soc Food Sci Nutr, 37, 405-409

41. Jang YS, Jeong JM (2010) Antioxidative effect and digestive enzyme inhibition of grape seed extract (GSE). J Korean Soc Food Sci Nutr, 39, 783-788

42. Kim MY, Lee SH, Jang GY, Park HJ, Li M, Kim SJ, Lee YR, Lee JS, Jeong HS (2014) The enzyme inhibitory activity of ethanol extracts derived from germinated rough rice (Oryza sativar L.) treated by high pressure. Korean J Food Sci Technol, 46, 44-50

43. Kim JH, Kim MU, Cho YJ (2007) Isolation and identification of inhibitory compound from Crataegi fructus on a-amylase and a-glucosidase. J Korean Soc Appl Biol Chem, 50, 204-209

44. Gua J, Jin YS, Han W, Shim TH, Sa JH, Wang MH (2006) Studies for component analysis, antioxidative activity and a-glucosidase inhibitory activity from Equisetum arvense. J Korean Soc Appl Biol Chem, 49, 77-81

45. Cho EK, Choi YJ (2013) Antioxidant, antidiabetic, and anti-inflammatory effects of extracts and fractions from Parthenocissus tricuspidata stems. J Life Sci, 23, 399-405

46. Xu ML, Wang L, Hu JH, Wang MH (2009) Antioxidant and a-glucosidase inhibitory activities of some wild vegetable extracts. J Agric Food Chem, 47, 4121-4125

47. Kim JW, Kim JK, Song IS, Kwon ES, Youn KS (2013) Comparison of antioxidant and physiological properties of Jerusalem artichoke leaves with different extraction processes. J Korean Soc Food Sci Nutr, 42, 68-75

48. Sharma B, Balomajumder C, Roy P (2008) Hypoglycemic and hypolipidemic effects of flavonoid rich extract from Eugenia jambolana seeds on streptozotocin induced diabetic rats. Food Chem Toxicol, 46, 2376-2383

49. Ryu JH, Kim RJ, Lee SJ, Kim IS, Lee HJ, Sung NJ (2011) Nutritional properties and biological activities of Artemisia annua L.. J Korean Soc Food Sci Nutr, 40, 163-170 